Article

\title{
Structural Characterizations of Aluminosilicates in Two Types of Fly Ash Samples from Shanxi Province, North China
}

\author{
Yunxia Liu ${ }^{1,2}$, Fangui Zeng ${ }^{1,2, * \mathbb{C}}$, Beilei Sun ${ }^{1,2}$, Peng Jia ${ }^{1,2}$ and Ian T. Graham ${ }^{3} \mathbb{C}$ \\ 1 Shanxi Key Laboratory of Coal and Coal-measure Gas Geology, Taiyuan University of Technology, \\ Taiyuan 030024, China; liuyunxiatyut0084@link.tyut.edu.cn (Y.L.); sunbeilei@tyut.edu.cn (B.S.); \\ zln521334@163.com (P.J.) \\ 2 Key Laboratory of Coal Science and Technology, Taiyuan University of Technology, Taiyuan 030024, China \\ 3 PANGEA Research Centre, School of Biological, Earth and Environmental Sciences, \\ University of New South Wales, Sydney NSW 2052, Australia; i.graham@unsw.edu.au \\ * Correspondence: zengfangui@tyut.edu.cn
}

Received: 13 March 2019; Accepted: 1 June 2019; Published: 12 June 2019

\begin{abstract}
In order to determine the structural characterization of aluminosilicates in two types of fly ashes, two samples from Shanxi Province, China were selected for study. One was from a pulverized coal boiler (FA-1), and the other from a circulating fluidized bed boiler (FA-2). FA-1 had a much higher content of silicon dioxide $\left(\mathrm{SiO}_{2}\right)(70.30 \%)$ than $\mathrm{FA}-2(42.19 \%)$, but aluminum oxide $\left(\mathrm{Al}_{2} \mathrm{O}_{3}\right)$ was higher in FA-2 (25.41\%) than in FA-1 (17.04\%). The characterizations were investigated using various methods including X-ray diffraction (XRD), Fourier transform infrared spectrometry (FTIR), magic angle spinning nuclear magnetic resonance (MAS-NMR) spectrometry, and X-ray photoelectron spectroscopy (XPS). The XRD analysis showed that FA-1 contained aluminosilicate glass, quartz and mullite, while FA-2 contained significant amounts of amorphous aluminosilicate, quartz and gypsum. The FTIR results showed an increased substitution of $\mathrm{Al}^{3+} \mathrm{for} \mathrm{Si}^{4+}$ as the band of asymmetric stretching vibrations $\mathrm{Si}-\mathrm{O}(\mathrm{Si})\left(1100 \mathrm{~cm}^{-1}\right)$ moved to $1090 \mathrm{~cm}^{-1}$ for FA-2, much lower than for FA-1 $\left(1097 \mathrm{~cm}^{-1}\right)$. Moreover, the sharpness of the bands in the $1250-1000 \mathrm{~cm}^{-1}$ region for FA-2 indicates that the silicate structure of FA-2 was more ordered than for FA-1. It can be understood from the ${ }^{29} \mathrm{Si}$ MAS-NMR results that $\mathrm{Q}^{4}(\mathrm{mAl})\left(\mathrm{Q}^{4}\right.$ are connected via 4 bridging $\mathrm{O}$ atoms to $\left.\mathrm{mAl}\right)$ is the main structural type in FA-1 and FA-2, and that FA-2 contains more Al, which substitutes for $\mathrm{Si}$ in the $\mathrm{Q}^{4}$ structure. ${ }^{27} \mathrm{Al}$ MAS-NMR demonstrated that a combination of tetrahedral, pentahedral, and octahedral Al existed in FA-1 and FA-2. The Si 2p XPS spectra suggested that there were three forms of $\mathrm{Si}$, including bridging $\mathrm{Si}\left(\mathrm{Si}-\mathrm{O}_{2}\right)$, non-bridging $\mathrm{Si}(\mathrm{Si}-\mathrm{O})$, and $\mathrm{SiO}_{2}$ gel. The content of $\mathrm{Si}-\mathrm{O}_{2}$ for $\mathrm{FA}-1$ was $37.48 \%$ higher than $\mathrm{Si}-\mathrm{O}(28.57 \%)$, while the content of $\mathrm{Si}-\mathrm{O}_{2}$ was $30.21 \%$ lower than $\mathrm{Si}-\mathrm{O}(40.15 \%)$ for FA-2. The Al 2p XPS spectra showed that octahedral Al was the dominant form for FA-1 with a content of $40.25 \%$, while the main phase was tetrahedral Al for FA-2 with a proportion of $37.36 \%$, which corresponds well with the ${ }^{27}$ Al MAS-NMR results.
\end{abstract}

Keywords: fly ash; structural characterizations; aluminosilicate; spectroscopic analysis; FTIR

\section{Introduction}

Globally, coal is the main primary energy source [1], and in 2018, coal combustion supplied $41 \%$ of the electricity generated in the world [2]. The most widely used combustors are the conventional pulverized coal (PC) combustor and the circulating fluidized bed (CFB) combustor. Compared with the conventional PC boiler, the CFB combustor suspends coal in upward-blowing jets of air during the combustion process, which can efficiently reduce emissions of $\mathrm{NO}_{X}$ and improve the in-situ 
desulfurization ability [3,4]. Moreover, the temperatures of the CFB combustor and PC combustor are $850-900{ }^{\circ} \mathrm{C}$ and $1400-1500{ }^{\circ} \mathrm{C}$, respectively, resulting in the formation of two types of fly ash samples with different characteristics [3]. The CFB fly ash has a higher content of unburned carbon, calcium sulfate and lime, does not contain mullite, and shows irregular lumps, but no glass balls [5]. Unburned carbon also exists in both types of fly ash (indicating an inefficient combustion), such as isotropic char formed from low-rank huminite/vitrinite and bituminous vitrinite, anisotropic cokes generated from bituminous vitrinite, and some partially combusted vitrinite obtained from anthracite vitrinite [6].

Fly ash can be considered as the world's fifth largest raw material resource [7]. Currently, one possible utilization of fly ash is in the synthesis of alkali-activated materials named geopolymers [8,9]. PC fly ash can successfully be used for the manufacturing of cement, building materials concrete, and concrete-admixed products [10], as it is categorized as a pozzolan, while CFB fly ash with a higher carbon content is broadly used as an insulator and adsorbent $[6,11]$. Another way to use fly ashes focuses on the critical elements contained within them [2,12,13]. Rare earth elements (REE; or expressed as REY when yttrium is included, as it has very similar geochemical characteristics to the REE) are strongly retained in the ash fraction and regarded as important potential resources [14-19]. Wang et al. [20] reported that $\mathrm{HCl}$ leaching of desilicated Luzhou fly ash achieved $88.15 \%$ of REY extraction efficiency. Dai et al. [21] conducted research on the fly ashes derived from three coal-hosted germanium (Ge) deposits and found that most of the Ge occurred in the form of Ge oxides (e.g., $\mathrm{GeO}_{2}$ ). Lithium(Li)-bearing coal seams have also been regarded as potential economic ore deposits by Sun et al. [22]. The concentration of Li from the combustion of such coals was found to be up to $408 \mu \mathrm{g} / \mathrm{g}$ in the coal ash of the Jungar Power Plant [12]. Hu et al. [23] found that 79-94\% of this $\mathrm{Li}$ was contained within glass particles and was strongly correlated with $\mathrm{Al}$ and Si. A number of other studies have shown that the critical elements, such as $\mathrm{Ga}, \mathrm{Al}, \mathrm{U}, \mathrm{Se}, \mathrm{Nb}$, and $\mathrm{Zr}$, can also be potentially extracted from coal fly ashes [24-29]. Compared with CFB fly ash, PC fly ash is more problematic for element extraction because abundant stable amorphous glass and mullite exist within it [30]. For these fly ashes, additives such as acid activation are used to break up the stable Al-O-Si bonds in the mullite [30].

In the process of utilization, the structural characteristics of fly ash have been studied to various degrees. Mozgawa et al. [31] used the middle infrared spectrum to describe the structure of the phases present in fly ash and found that the aluminosilicates induced a shift in the T-O stretching band at $950-1100 \mathrm{~cm}^{-1}$. Gao et al. [32] applied ${ }^{29} \mathrm{Si}$ and ${ }^{27} \mathrm{Al}$ magic angle spinning nuclear magnetic resonance (MAS-NMR) to determine the extent of the reaction within alkali-activated slag-fly ash and found that the increase in the activator modulus could lead to a reduction in the slag reactivity, together with significantly increased $\mathrm{Q}^{3}(1 \mathrm{Al})$ and reduced $\mathrm{Q}^{2}(1 \mathrm{Al})$ groups. Kanuchova et al. [8,33] used X-ray photoelectron spectroscopy (XPS) to monitor the changes in chemical bonds (such as for the $\mathrm{Si}-\mathrm{O}-\mathrm{Al}-\mathrm{O}$ bond) in the creation of geopolymers and also investigated the mechanical activation of fly ash. $\mathrm{Hu}$ [23] used ${ }^{29} \mathrm{Si}$ MAS-NMR and energy calculations to predict that Li occurrence within the $\mathrm{Q}^{3}(0 \mathrm{Al})$ and $\mathrm{Q}^{3}(1 \mathrm{Al})$ structures through the reaction with $\mathrm{Q}^{4}(0 \mathrm{Al})$ and $\mathrm{Q}^{4}(1 \mathrm{Al})$.

Previous studies on the properties of the two types of fly ash have mostly focused on their mineral composition, morphology [5], chemical, physical, and optical properties [34,35]. Structural studies of fly ashes have been limited to the structural changes that occur in the utilization of fly ash for current applications, such as alkali activation, mechanical activation, and the interactions between the elements present and the silicon framework. In general, the maximum limit of unburned carbon in fly ash is $3 \mathrm{wt} \%$ for many applications [6]. In order to meet this requirement, a better understanding of the structural characterization between the two types of fly ash is beneficial for their subsequent utilization, whether they are to be used in the production of geopolymers or for the extraction of contained elements of economic interest such as Li. However, current research related to this is greatly lacking. Therefore, in this paper, the structure of aluminosilicates in two types of fly ash samples have 
been well-characterized using XRD, FTIR, MAS-NMR, and XPS techniques, with the aim of providing a basic data set and greater understanding of fly ash for use in geopolymers or element extraction.

\section{Samples and Methods}

\subsection{Samples}

Shanxi is a major coal-producing province in northern China and a major region for coal-fired power generation. Taiyuan City, as the capital city of Shanxi Province, has attracted attention regarding its solid waste, such as fly ash. The Xishan Coalfield Group is the largest base of coking coal production in China and is part of the "coal-electricity-building materials" industrial chain. Thus, two coal-fired power plants in this group were selected for this study. One sample was collected from the Gujiao Power Plant (FA-1) and the other was collected from the Xishan Thermal Power Plant (FA-2). The Gujiao Power Plant is the largest coal middlings-fired pithead power plant in China, and also the largest power plant in Taiyuan City. The Xishan Thermal Power Plant was independently set-up by a coal mine and the generated electricity is used by this group. It was recognized as belonging to the "comprehensive utilization of power plants" by the National Development and Reform Commission in 2008. The samples were collected from the electrostatic precipitator hopper of the power plants over a five-day period. The feed coal for the Gujiao Power Plant comprises run-of-mine coal, middlings and slime from the Tunlan, Malan, Dongqu, Xiqu, and Zhengchengdi mines. The feed coal for the Xishan Thermal Power Plant is run-of-mine coal, gangue and slime from the Baijiazhuang and Guandi mines. Further details are shown below in Table 1.

Table 1. Information on the two power plants sampled in this study.

\begin{tabular}{ccccc}
\hline Samples & Power Plant & Style & Capacity & Utilization \\
\hline FA-1 & Gujiao Power Plant & Four-corner tangential & $2 \times 300 \mathrm{MW}+2 \times 600 \mathrm{MW}$ & Gujiao cement plant \\
FA-2 & Xishan Thermal Power Plant & Fluidization & $3 \times 660$ MW & Huatong brick company \\
\hline
\end{tabular}

\subsection{Major and Trace Element Chemistry}

The samples were crushed and ground to less than 200 mesh. A preliminary ashing was not conducted on the samples, and the pre-treatment for the geochemical analysis used the method of Qi et al. [36]. Trace elements were determined using a PE ELAN DRC-e inductively coupled plasma mass spectrometry (ICP-MS). Certified standard references included OU-6 (slate), AMH-1 (andesite) and GBPG-1 (plagiogneiss). The accuracies of the ICP-MS analyses were estimated to be better than $\pm 5-10 \%$ (relative) for most elements. The major elements were measured by ICP-OES (Agilent 720 ) with GSR-3, GSD-4, GSD-6, OU-6, GSR-12, and GSR-13 being the standards used for the major elements. The analytical accuracies were estimated to be $\pm 2 \%$ (relative) for the major oxides present in concentrations greater than $1 \mathrm{wt} \% . \mathrm{SiO}_{2}$ was measured using the traditional gravimetric method following GB/T 14506.3-2010 [37]. Although instrumental analysis has become the main analytical method, a chemical analysis has unique advantages, such as the accuracy and scope of application [38,39], and the gravimetric method is still used in research [40,41].

\section{3. $X R D$}

An X-ray diffraction (XRD) analysis was carried-out using a Rigaku MiniFlex600 type X-ray diffractometer (Rigaku Corporation, located in Taiyuan University of Technology) with an accelerating voltage of $40 \mathrm{kV}$ and current of $15 \mathrm{~mA}$. The samples were scanned over the $2 \theta$ range of 5 to $85^{\circ}$ using $\mathrm{Cu}-\mathrm{K} \alpha$ radiation with a step-size of $0.02^{\circ}$. The crystalline phases were identified using the International Centre for Diffraction Data powder diffraction database. 


\subsection{FTIR}

The Fourier transform infrared (FTIR) spectra were measured on a Bruker VERTEX 70v vacuum spectrometer (Swiss Bruker, located in Taiyuan University of Technology). They were collected in the mid region of $4000-400 \mathrm{~cm}^{-1}$ after 256 scans at a $4 \mathrm{~cm}^{-1}$ resolution. The samples were prepared using the standard $\mathrm{KBr}$ pellet method. FTIR belongs to the field of molecular vibrational spectroscopy and is known as the "fingerprint" technology for the identification of functional groups. It has also been used to conduct a great deal of research into the molecular structure of coal and minerals in sedimentary rocks according to the unique absorption pattern of minerals based on their composition [42-44].

\subsection{MAS-NMR}

Solid-state magic angle spinning nuclear magnetic resonance (MAS-NMR) spectra were acquired using a Bruker Avance III $600 \mathrm{MHz}$ Wide Bore spectrometer (14.1T) (Swiss Bruker, ThermoFisher Scientific, located in Shanxi Institute of Coal Chemistry, Chinese Academy of Sciences). the resonance frequencies used were 79.5 and $104.3 \mathrm{MHz}$. The ${ }^{29} \mathrm{Si}$ NMR spectra were collected on a $4 \mathrm{~mm}$ probe, with a spinning rate at $10 \mathrm{kHz}$, and the chemical shifts were referenced to tetramethylsilane (TMS) at $0 \mathrm{ppm}$. The ${ }^{27} \mathrm{Al}$ MAS-NMR spectra were obtained by using a $4 \mathrm{~mm}$ probe with $\mathrm{ZrO}_{2}$ rotor 8996 , with a spinning rate at $13 \mathrm{kHz}$ and a pulse length of $2.8 \mu \mathrm{s}$; the chemical shifts were referenced to $1 \mathrm{M}$ $\mathrm{Al}\left(\mathrm{NO}_{3}\right)_{3}$ solution at $0 \mathrm{ppm}$. Previous to the NMR spectra recordings, we used a strong magnetic field to remove the magnetic materials from the samples [45].

\subsection{XPS}

The X-ray photoelectron spectroscopy (XPS) experiments were performed using a thermo escalab 250 electron spectrometer (ThermoFisher Scientific, located in Shanxi Institute of Coal Chemistry, Chinese Academy of Sciences) with A1Ka $(1486.6 \mathrm{eV})$. The measurements were conducted with a pass energy of $20 \mathrm{eV}$, and the energy resolution was $0.05 \mathrm{eV}$. The sample chamber was evacuated to $10^{-7} \mathrm{~Pa}$ during the experiments. All the absolute binding energies were calibrated by C1s (284.6 eV).

\section{Results and Discussion}

\subsection{Properties of the $F A$}

\subsubsection{Major and Trace Element Chemistry}

Compared to the average values of major-element oxides for Chinese coals, the contents of $\mathrm{SiO}_{2}$ and $\mathrm{Al}_{2} \mathrm{O}_{3}$ are much higher in the feed coals for FA-1 and FA-2 (Table 2), while $\mathrm{CaO}$ and $\mathrm{Fe}_{2} \mathrm{O}_{3}$ are lower. The remaining major element oxides are either slightly higher than or close to the average values for Chines coals. Moreover, the chemical composition of FA-1 and FA-2 varies significantly due to the differing feed coal properties and the type of combustion boiler used. Compared to the feed coal for FA-1, the feed coal for FA-2 contains more gangue and slime; therefore, it has higher $\mathrm{SiO}_{2}$ and $\mathrm{Al}_{2} \mathrm{O}_{3}$ contents and lower LOI (Table 2). As for the trace elements shown in Figure 1, compared to the average values for world hard coals, $\mathrm{Li}$ is enriched in both feed coals, with concentration coefficients of 5.06 and 6.91. $\mathrm{Zr}$ and Th are also enriched in the feed coal for FA-1 and the feed coal for FA-2, respectively. The feed coal for FA-1 is slightly enriched in $\mathrm{Ga}, \mathrm{Y}, \mathrm{Nb}, \mathrm{La}, \mathrm{Ce}, \mathrm{Hf}, \mathrm{Ta}, \mathrm{Pb}$, Th and $\mathrm{U}$. The remaining trace elements are either depleted or similar to average world coal concentrations in the feed coal for FA-1. A greater number of trace elements are enriched in the feed coal for FA-2, with concentration coefficients between 2 and 5 for Sc, V, Cr, Ga, Y, Zr, Nb, Mo, Cs, La, Ce, Pr, Nd, Sm, Eu, Tb, Er, Yb, Hf, $\mathrm{Ta}, \mathrm{Pb}$, and $\mathrm{U}$. 
Table 2. Chemical composition of the feed coals for FA-1 and FA-2.

\begin{tabular}{cccccccccccc}
\hline $\begin{array}{c}\text { Chemical } \\
\text { Composition (\%) }\end{array}$ & $\mathbf{S i O}_{2}$ & $\mathrm{Al}_{\mathbf{2}} \mathrm{O}_{\mathbf{3}}$ & $\mathbf{N a}_{\mathbf{2}} \mathbf{O}$ & $\mathbf{K}_{\mathbf{2}} \mathbf{O}$ & $\mathrm{CaO}$ & $\mathbf{M g O}$ & $\mathbf{P}_{2} \mathrm{O}_{\mathbf{5}}$ & $\mathrm{TiO}_{2}$ & $\mathbf{M n O}$ & $\mathrm{Fe}_{2} \mathrm{O}_{3}$ & $\mathbf{L O I}$ \\
\hline Feed coal of FA-1 & 17.49 & 9.09 & 0.11 & 0.28 & 0.82 & 0.12 & 0.25 & 0.40 & 0.01 & 1.64 & 69.37 \\
Feed coal of FA-2 & 34.76 & 18.05 & 0.16 & 0.81 & 0.74 & 0.28 & 0.07 & 0.72 & 0.02 & 3.82 & 40.66 \\
Chinese coal * & 8.47 & 5.98 & 0.16 & 0.19 & 1.23 & 0.22 & 0.092 & 0.33 & 0.015 & 4.85 & - \\
\hline
\end{tabular}

* Average values for major-element oxides for Chinese coals from Dai et al., 2012 [46].
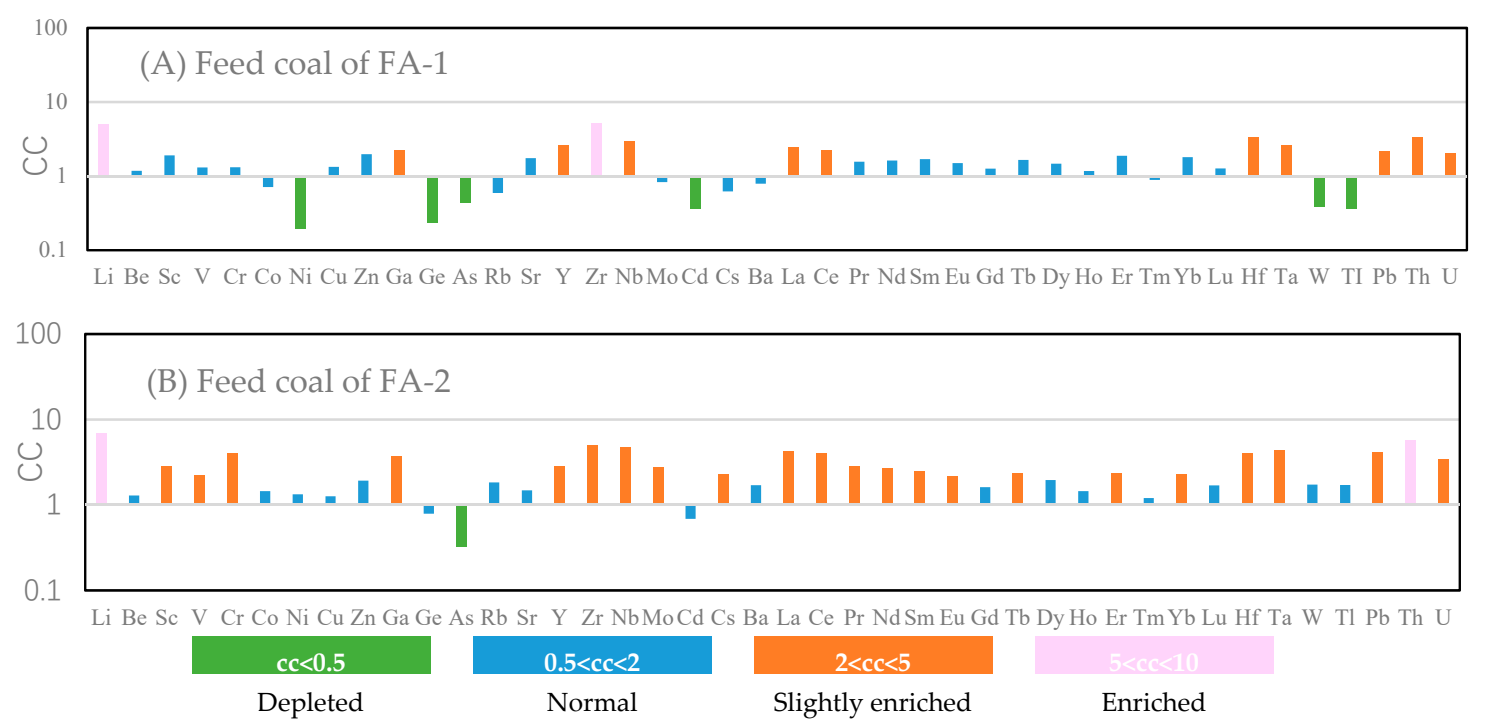

Figure 1. Concentration coefficients (CC) for trace elements in the feed coals for FA-1 and FA-2, normalized to average trace-element concentrations in world hard coals from Ketris and Yudovich, 2009 [47].

After combustion, $\mathrm{SiO}_{2}$ and $\mathrm{Al}_{2} \mathrm{O}_{3}$ are the dominant oxides in the two ash samples (Table 3). Because of the lower combustion temperature of the circulating fluidized bed $\left(800-850{ }^{\circ} \mathrm{C}\right)$, FA-2 combusted incompletely and thus has a high LOI value. FA-1 has significantly more $\mathrm{SiO}_{2}$ (70.30\%) than FA-2 (42.19\%), but both $\mathrm{Al}_{2} \mathrm{O}_{3}(25.41 \mathrm{wt} \%$ compared to $17.04 \mathrm{wt} \%)$ and $\mathrm{Fe}_{2} \mathrm{O}_{3}(6.50 \mathrm{wt} \%$ compared to $3.23 \mathrm{wt} \%$ ) are higher in FA-2 than in FA-1 (17.04\%). The remaining major-element oxides for the two fly ashes are close to each other. As for the trace elements (Figure 2), most trace elements in both FA-1 and FA-2 are either lower than or close to the average values for world hard coal ashes. However, the concentration of Li in FA-1 is $211.81 \mu \mathrm{g} / \mathrm{g}, 2.58$ times higher than in average world hard coal ashes $(82 \mu \mathrm{g} / \mathrm{g})$ [47]. Also, $\mathrm{Zr}$ and Th are slightly enriched in FA-1 with concentration coefficients of 2.29 and 1.35. $\mathrm{Pb}$ is greatly enriched in FA-2 with a concentration of $80.6 \mu \mathrm{g} / \mathrm{g}$, higher than that of the average value for world hard coal ashes of $12 \mu \mathrm{g} / \mathrm{g}$.

Table 3. Chemical composition of FA-1 and FA-2.

\begin{tabular}{cccccccccccc}
\hline $\begin{array}{c}\text { Chemical } \\
\text { Composition(\%) }\end{array}$ & $\mathrm{SiO}_{2}$ & $\mathrm{Al}_{2} \mathrm{O}_{3}$ & $\mathbf{N a}_{2} \mathrm{O}$ & $\mathrm{K}_{2} \mathrm{O}$ & $\mathrm{CaO}$ & $\mathrm{MgO}$ & $\mathbf{P}_{2} \mathrm{O}_{5}$ & $\mathrm{TiO}_{2}$ & $\mathrm{MnO}$ & $\mathrm{Fe}_{2} \mathrm{O}_{3}$ & LOI \\
\hline FA-1 & 70.30 & 17.04 & 0.17 & 0.93 & 1.79 & 0.32 & 0.19 & 1.39 & 0.03 & 3.23 & 4.62 \\
FA-2 & 42.19 & 25.41 & 0.25 & 1.08 & 1.84 & 0.49 & 0.14 & 1.06 & 0.03 & 6.50 & 21.57 \\
\hline
\end{tabular}




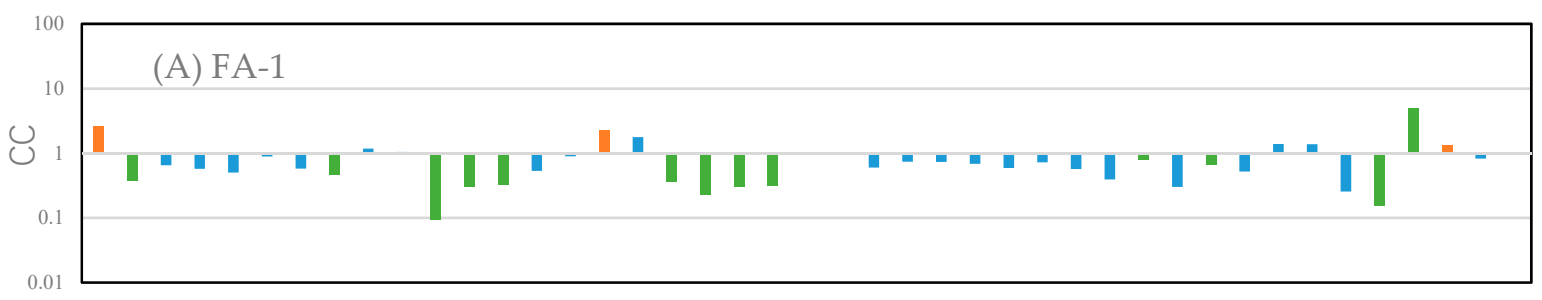

Li Be Sc V Cr Co Ni Cu Zn Ga Ge As Rb Sr Y Zr NbMoCd Cs Ba La Ce Pr NdSm Eu Gd Tb Dy Ho Er Tm Yb Lu Hf Ta W TI Pb Th U

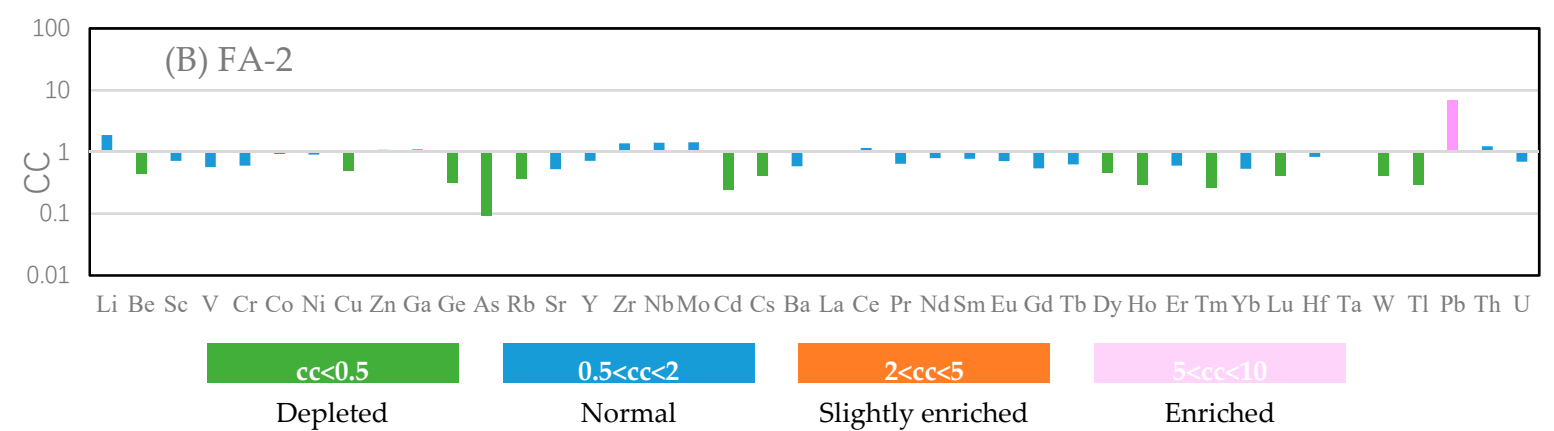

Figure 2. Concentration coefficients (CC) for trace elements in FA-1 and FA-2, normalized to average trace-element concentrations in world hard coal ashes from Ketris and Yudovich, 2009 [47].

\subsubsection{Mineralogy}

FA-1 is a pulverized coal-fired fly ash. In this type of boiler, powdered coal was sprayed into the boiler [48-50] and was burned at temperatures above $1200{ }^{\circ} \mathrm{C}$. The XRD pattern for this fly ash has an amorphous hump between $15^{\circ}$ and $30^{\circ} 2 \theta$ and also contains crystalline quartz $\left(\mathrm{SiO}_{2}\right)$ and mullite $\left(\mathrm{Al}_{6} \mathrm{Si}_{2} \mathrm{O}_{13}\right)$ (Figure 3a). During coal combustion in power plants, mullite is typically found in fly ashes formed using this process. The high content of mullite in FA-1 (Figure 3a) is related to the kaolinite in the feed coal (Figure 3b), which is consistent with results reported in the literature [12,51]. Needle-like mullite crystals on glass spheres (Figure 4) indicate that the mullite crystallized from the amorphous aluminosilicate melt during the combustion but did not transform directly from kaolinite [12]. The various spherical shapes of many fly ash particles suggest that they were solidified from a viscous fluid state [52].
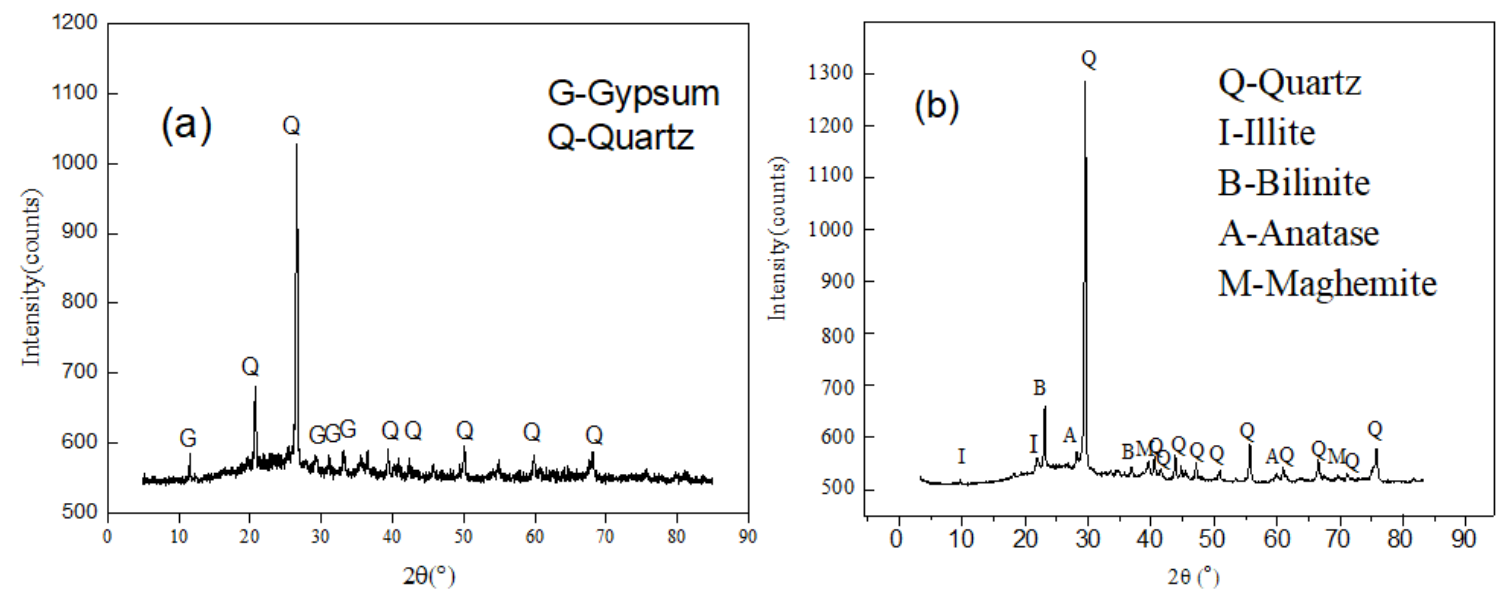

Figure 3. X-ray diffraction (XRD) patterns for FA-1(a) and the feed coal for FA-1(b). 


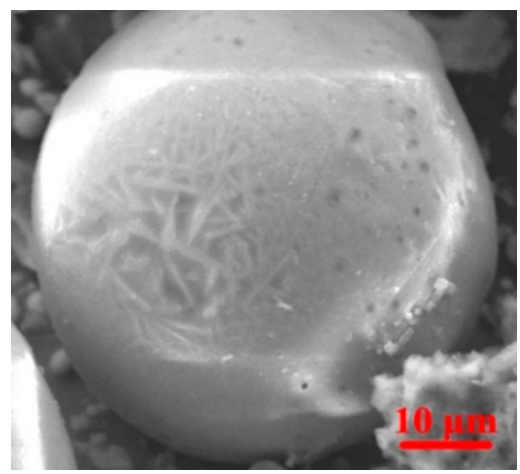

Figure 4. Scanning electron microscope (SEM) image of the glass sphere containing mullite in FA-1.

FA-2 is a circulating fluidized bed fly ash. The circulating fluidized bed boiler can use washed coal, tail coal, and gangue. The feed coal for FA- 2 contained illite, bilinite, anatase and maghemite (Figure $5 b$ ). In the fly ash sample for FA-2, the amorphous phase is dominant, but it also contained less quartz and gypsum (Figure 5a). Clay minerals, such as illite, did not melt to form mullite, which is related to the lower temperature of the boiler $\left(800-850^{\circ} \mathrm{C}\right)$ [48-50]. Quartz was the remaining phase from the feed coal, and gypsum formed in the desulfurization process through absorption and oxidation.
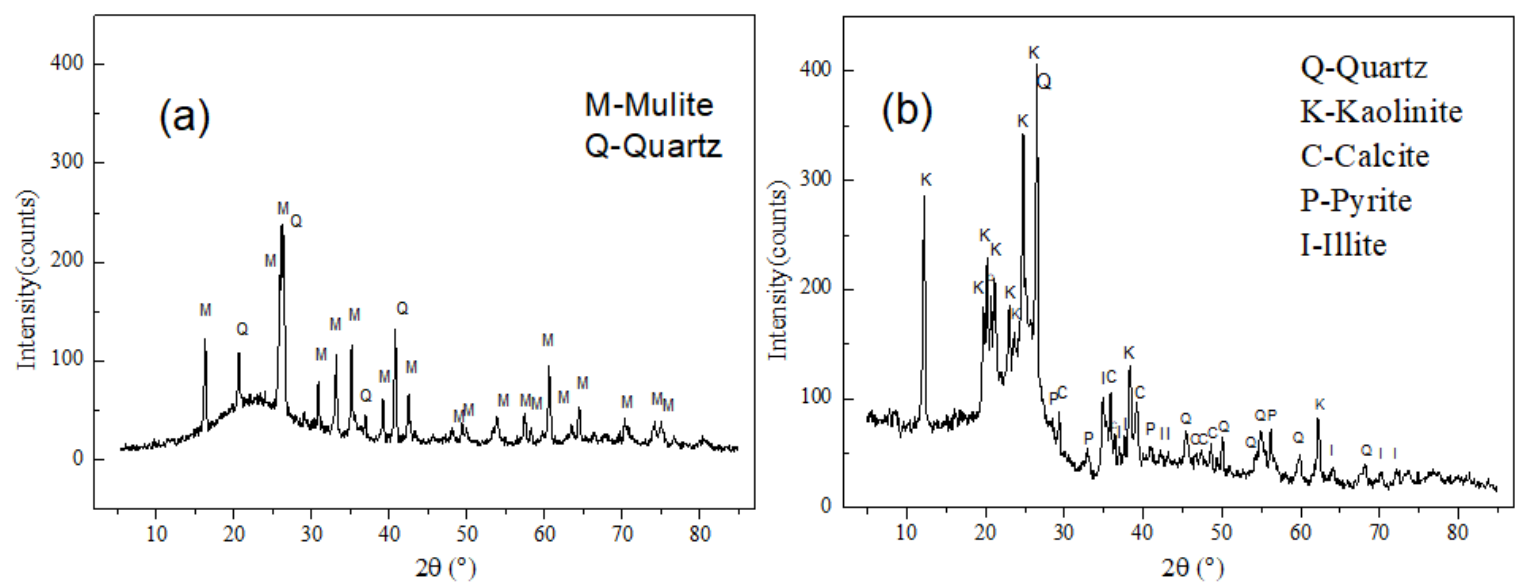

Figure 5. XRD patterns for FA-2 (a) and the feed coal for FA-2 (b).

\subsection{FTIR}

FTIR spectra contain information on the mineralogical composition because each mineral has a unique absorption pattern in the mid-IR range [44]. Infrared spectroscopy is a widely used method for the study of aluminosilicates in fly ash [53,54], especially in the presence of amorphous phases [31]. The second derivative spectrum for the samples was determined according to the methods in the literature $[55,56]$, and the position of the trough reflects the peak wave number of the initial FTIR spectrum.

As shown in Figure 6, at first, the vibration bands present in the two samples were analyzed (Figure 6). The bands appearing at around $3400 \mathrm{~cm}^{-1}$ and $1625 \mathrm{~cm}^{-1}$ are attributed to the stretching vibration and bending vibration of $\mathrm{OH}$ in $\mathrm{H}_{2} \mathrm{O}$ molecules, respectively, indicating that a small amount of molecular water is present [31,57]. The most intense band observed for both FA-1 and FA-2 is at approximately $1100 \mathrm{~cm}^{-1}$, and is attributed to the asymmetric stretching vibrations of $\mathrm{Si}-\mathrm{O}(\mathrm{Si})$ [31]. At the same time, the position at around $1100 \mathrm{~cm}^{-1}$ is indicative of the "pure" silica structure, and the $\mathrm{Al} / \mathrm{Si}$ ratio increases with the decreasing values of wavenumbers due to the substitution of aluminum atoms for Si at the tetrahedral position [31,58]. It can be seen from the spectra (Figure 6b) that this band for FA-2 moves to $1090 \mathrm{~cm}^{-1}$, much lower than that of FA-1 $\left(1097 \mathrm{~cm}^{-1}\right)$, indicating that there was more $\mathrm{Al}$ in FA-2 to replace $\mathrm{Si}$ in the tetrahedron. Moreover, the bands in the $1250-1000 \mathrm{~cm}^{-1}$ region 
of FA-2 are sharper than the bands for FA-1, which is attributed to the increased order of the silicate structure [54].
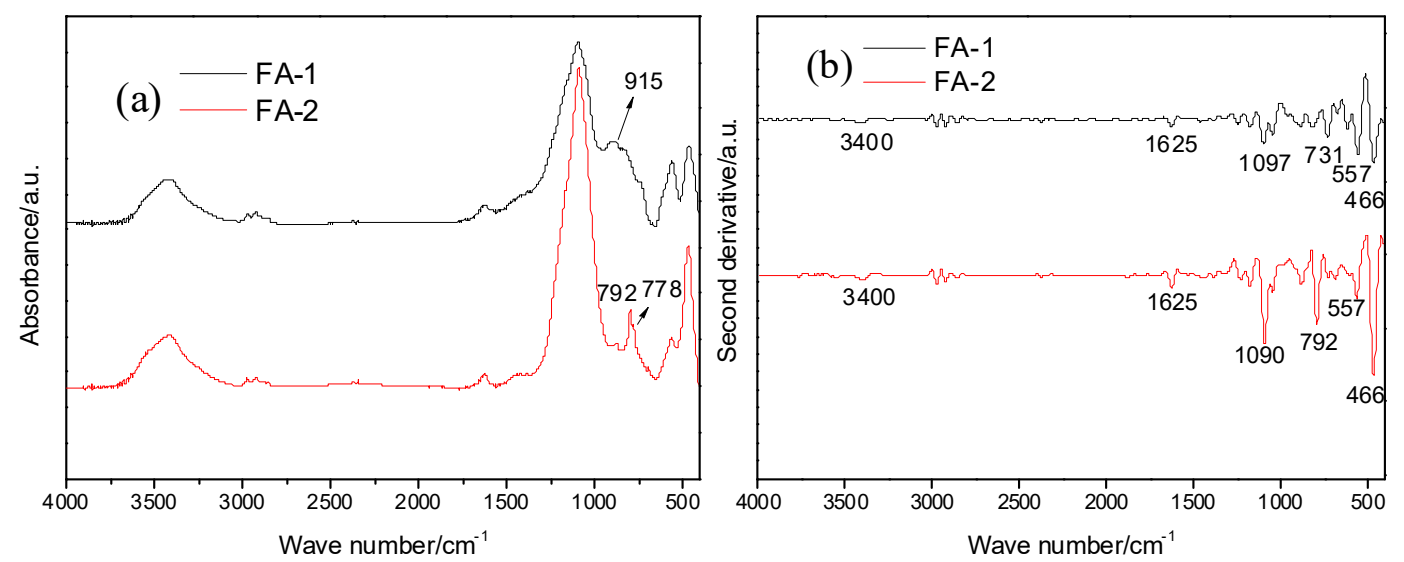

Figure 6. Original (a) and second derivative (b) Fourier transform infrared (FTIR). spectra for FA-1 and FA-2.

Second, some common bands for FA-1 and FA-2 were observed (Figure $6 \mathrm{~b}$ ). The bands at $557 \mathrm{~cm}^{-1}$ are attributed to $\mathrm{Si}-\mathrm{O}-\mathrm{Al}$ vibrations in the coal ash samples, which formed from the structural rearrangement of the Si-O-Al vibrations in coal [54], and the intense band at $557 \mathrm{~cm}^{-1}$ present in FA-1 can be explained by the substitution of $\mathrm{Al}$ for $\mathrm{Si}$ in the mullite structure [59]. The bands at around $466 \mathrm{~cm}^{-1}$ for FA-1 and FA-2 are connected with the bending vibrations of O-Si-O present in the silicate tetrahedron [31].

There are also some different vibration bands between the two samples (Figure 6a). FA-1 shows a shoulder peak at about $915 \mathrm{~cm}^{-1}$ associated with the presence of aluminum in the octahedral position, confirming the existence of mullite [59]. The doublet bands at $778 \mathrm{~cm}^{-1}$ and $792 \mathrm{~cm}^{-1}$ in FA-2 are associated with the symmetric stretching vibrations of the $\mathrm{Si}-\mathrm{O}-\mathrm{Si}$ bridges $[31,44]$.

\subsection{MAS-NMR}

\subsection{1. ${ }^{29}$ Si MAS-NMR}

In addition to XRD and FTIR, MAS-NMR spectroscopy provides a new perspective to analyze the chemical properties of the sample, and this analytical method has gradually become more widely used [60-63]. The deconvolution quantitative analysis of the obtained spectra can provide further information, such as changes in the structure and chain length. Meanwhile, information on $\mathrm{Q}^{\mathrm{n}}(\mathrm{mAl})$ sites can also be obtained, where $\mathrm{Q}^{\mathrm{n}}$ are connected via bridging $\mathrm{O}$ to $\mathrm{mAl}$ atoms, including $\mathrm{Q}^{0}$ (monomers), $\mathrm{Q}^{1}$ (dimers), and $\mathrm{Q}^{2}$ (bridging groups) [60,64-66], $\mathrm{Q}^{3}$ and $\mathrm{Q}^{4}$. Fly ash typically exhibits overlapping resonance peaks at $-80 \mathrm{ppm}$ to $-120 \mathrm{ppm}[60,61]$, indicating the presence of different structure types of $\mathrm{Q}^{\mathrm{n}}(\mathrm{mAl}) . \mathrm{Q}^{4}(\mathrm{mAl})$ is the dominant structure type in fly ash, and there are generally nine sites, identified as $\mathrm{Q}^{4}(\mathrm{mAl}, \mathrm{m}=0-4)(-86,-90,-94,-98,-101,-104,-108,-112$, -116 ppm) $[45,67,68]$.The ${ }^{29}$ Si MAS-NMR spectra for FA-1 and FA-2 are shown in Figure 7 , and the results of the deconvolution are listed in Table 4 and are shown in Figure 8. For FA-1, as shown in Table 4 , there are seven sites which were identified as being $\mathrm{Q}^{4}(\mathrm{mAl}, \mathrm{m}=0-4)$; furthermore, the sites at $-82 \mathrm{ppm}$ are assigned to $\mathrm{Q}^{2}(1 \mathrm{Al})$ [32]; these resonance sites are contributed by the amorphous glass, mullite, and quartz. As for FA-2, there are nine sites which were identified after the peak fitting, and these are present due to the amorphous phase and quartz. It can be seen from Figure 8 that $\mathrm{Q}^{4}(\mathrm{mAl})$ is the main structure type in FA-1 and FA-2, with a small amount of $\mathrm{Q}^{2}(1 \mathrm{Al})[67,69-71]$. For both FA-1 and FA-2, the percentage of $\mathrm{Q}^{4}(\mathrm{mAl})$ decreases as the $\mathrm{m}$ value increases. Compared with FA-1, FA-2 has a lower percentage of $\mathrm{Q}^{4}(0 \mathrm{Al}), \mathrm{Q}^{4}(1 \mathrm{Al})$, and $\mathrm{Q}^{4}(2 \mathrm{Al})$, and a higher content of $\mathrm{Q}^{4}(3 \mathrm{Al})$ and $\mathrm{Q}^{4}(4 \mathrm{Al})$. 
Furthermore, the greater substitution of $\mathrm{Al}$ for $\mathrm{Si}$ in the $\mathrm{Q}^{4}$ structure reflects the higher reactivity of FA-2 [32].
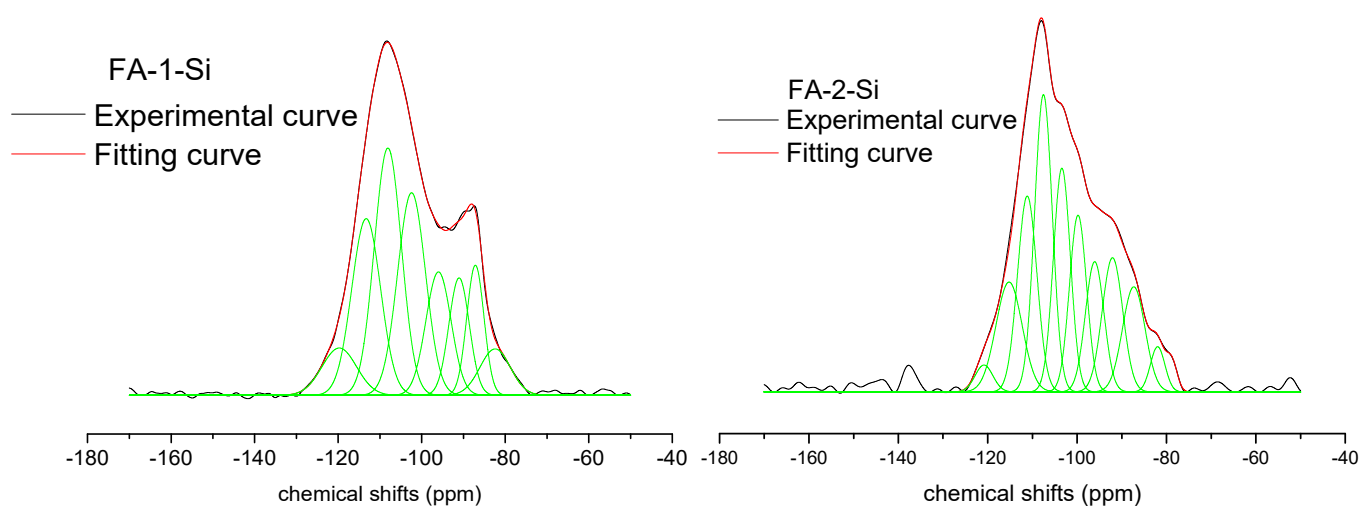

Figure 7. The ${ }^{29}$ Si magic angle spinning nuclear magnetic resonance (MAS-NMR) spectra for FA-1 and FA-2.

Table 4. The deconvolution results of the ${ }^{29}$ Si MAS-NMR spectra for FA-1 and FA-2.

\begin{tabular}{cccccc}
\hline & FA-1 & & \multicolumn{3}{c}{ FA-2 } \\
\hline CenterMAX/ppm & Arearfit/\% & Adscription & CenterMAX/ppm & Arearfit/\% & Adscription \\
\hline-119.73438 & 5.7954 & $\mathrm{Q}^{4}(0 \mathrm{Al})$ & -120.83294 & 1.74 & $\mathrm{Q}^{4}(0 \mathrm{Al})$ \\
-113.29738 & 18.03134 & $\mathrm{Q}^{4}(0 \mathrm{Al})$ & -115.22508 & 10.50 & $\mathrm{Q}^{4}(0 \mathrm{Al})$ \\
-108.10059 & 23.7302 & $\mathrm{Q}^{4}(1 \mathrm{Al})$ & -111.1572 & 10.82 & $\mathrm{Q}^{4}(0 \mathrm{Al})$ \\
-102.42915 & 20.05077 & $\mathrm{Q}^{4}(2 \mathrm{Al})$ & -107.53395 & 19.17 & $\mathrm{Q}^{4}(1 \mathrm{Al})$ \\
-95.99105 & 10.99791 & $\mathrm{Q}^{4}(3 \mathrm{Al})$ & -103.40652 & 13.88 & $\mathrm{Q}^{4}(2 \mathrm{Al})$ \\
-91.05172 & 8.48707 & $\mathrm{Q}^{4}(4 \mathrm{Al})$ & -99.79292 & 10.99 & $\mathrm{Q}^{4}(3 \mathrm{Al})$ \\
-87.15833 & 7.91601 & $\mathrm{Q}^{4}(4 \mathrm{Al})$ & -96.0613 & 8.83 & $\mathrm{Q}^{4}(3 \mathrm{Al})$ \\
-82.4267 & 4.99129 & $\mathrm{Q}^{2}(1 \mathrm{Al})$ & -92.0807 & 13.06 & $\mathrm{Q}^{4}(4 \mathrm{Al})$ \\
& & & -87.31883 & 8.62 & $\mathrm{Q}^{4}(4 \mathrm{Al})$ \\
& & & -81.98463 & 2.39 & $\mathrm{Q}^{2}(1 \mathrm{Al})$ \\
\hline
\end{tabular}

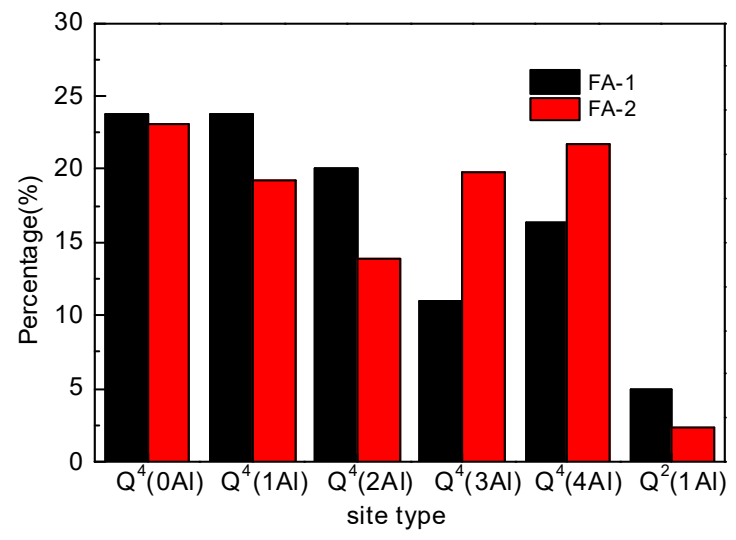

Figure 8. Comparison of the silicate compositions for FA-1 and FA-2.

\subsection{2. ${ }^{27} \mathrm{Al}$ MAS-NMR}

${ }^{27} \mathrm{Al}$ MAS-NMR can provide information regarding the 4-6 coordination environment of aluminium and the corresponding chemical shift in fly ash. The aluminium can be generally identified as three types from the resonance spectrum: $50-100 \mathrm{ppm}$ for tetrahedral aluminium, 30-40 ppm for pentahedral aluminium and -10-20 ppm for octahedral aluminium [32].

The ${ }^{29} \mathrm{Al}$ MAS-NMR spectra for FA-1 and FA-2 are shown in Figure 9, and the results of the deconvolution are listed in Table 5 and are shown in Figure 10. As shown in Figure 9, the wide resonance range for FA- 1 and $\mathrm{FA}-2$ at $-50 \mathrm{ppm}$ to $100 \mathrm{ppm}$ indicates a combination of $\mathrm{Al}(\mathrm{IV}), \mathrm{Al}(\mathrm{V})$, 
and $\mathrm{Al}(\mathrm{VI})$ instead of a single $\mathrm{Al}$. This can be attributed to the structure of the glass and the amorphous phase present in both samples [32,70,72]. Under high temperature conditions, Al(IV) can undergo an isomorphous substitution with $\mathrm{Si}$ to form an aluminosilicate [73]. In terms of FA-1, a narrow octahedral Al peak is observed at around $2 \mathrm{ppm}$, and it has been reported that the resonance at this site is attributed to the $\mathrm{Al}$ components from mullite with a negligible reactivity [32]. Compared to FA-1, FA-2 has a higher content of tetrahedral Al (Figure 10). This tetrahedral Al and tetrahedral Si can combine with oxygen to form $\mathrm{Q}^{\mathrm{n}}(\mathrm{mAl})$; FA-2 has a higher $\mathrm{Al}$ content in $\mathrm{Q}^{\mathrm{n}}(\mathrm{mAl})$ than FA-1 due to the higher content of tetrahedral $\mathrm{Al}$, consistent with the results of the ${ }^{29} \mathrm{Si}$ MAS-NMR analysis.
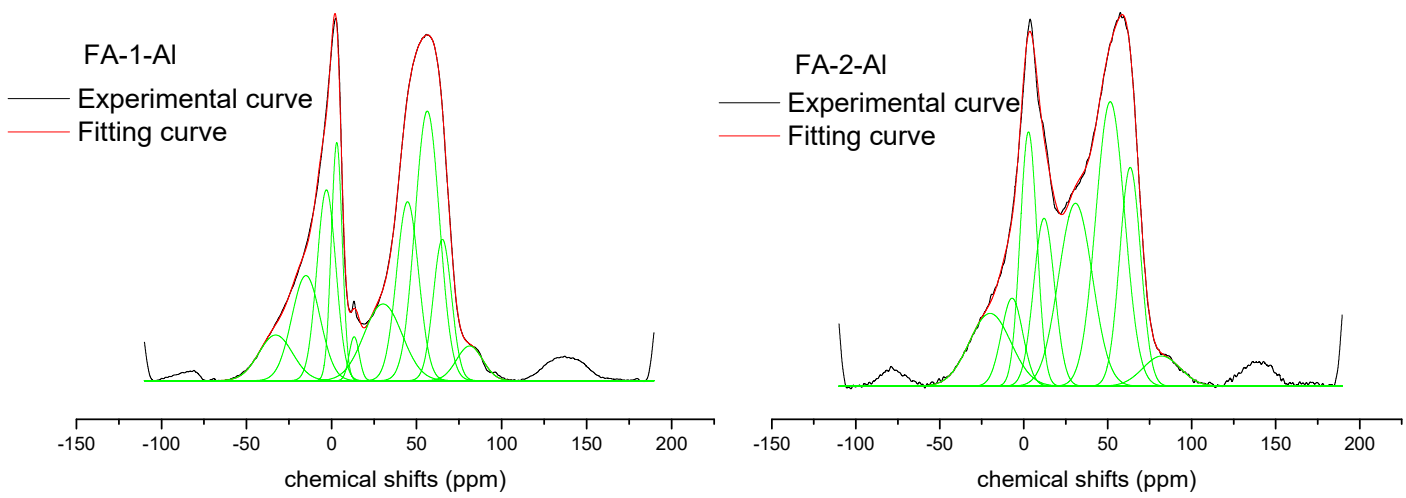

Figure 9. The ${ }^{27} \mathrm{Al}$ MAS-NMR spectra for FA-1 and FA-2.

Table 5. The deconvolution results of the ${ }^{27} \mathrm{Al}$ MAS-NMR spectra for FA-1 and FA-2.

\begin{tabular}{cccccc}
\hline \multicolumn{2}{c}{ FA-1 } & \multicolumn{3}{c}{ FA-2 } \\
\hline CenterMAX/ppm & Arearfit/\% & Adscription & CenterMAX/ppm & Arearfit/\% & Adscription \\
\hline-32.85115 & 5.50545 & $\mathrm{Al}(\mathrm{VI})$ & -20.04621 & 9.25597 & $\mathrm{Al}(\mathrm{VI})$ \\
-15.05214 & 10.60196 & $\mathrm{Al}(\mathrm{VI})$ & -6.95479 & 5.74581 & $\mathrm{Al}(\mathrm{VI})$ \\
-3.01684 & 12.81897 & $\mathrm{Al}(\mathrm{VI})$ & 2.81933 & 13.01829 & $\mathrm{Al}(\mathrm{VI})$ \\
3.06664 & 9.18837 & $\mathrm{Al}(\mathrm{VI})$ & 12.09294 & 10.68981 & $\mathrm{Al}(\mathrm{VI})$ \\
13.30475 & 1.56215 & $\mathrm{Al}(\mathrm{VI})$ & 30.80117 & 18.82657 & $\mathrm{Al}(\mathrm{V})$ \\
30.28845 & 10.44299 & $\mathrm{Al}(\mathrm{V})$ & 51.49316 & 25.06484 & $\mathrm{Al}(\mathrm{IV})$ \\
44.71206 & 14.05927 & $\mathrm{Al}(\mathrm{V})$ & 63.36683 & 13.99035 & $\mathrm{Al}(\mathrm{IV})$ \\
56.30446 & 23.41921 & $\mathrm{Al}(\mathrm{IV})$ & 82.02285 & 3.40836 & $\mathrm{Al}(\mathrm{IV})$ \\
65.19928 & 9.17178 & $\mathrm{Al}(\mathrm{IV})$ & & & \\
81.20427 & 3.22987 & $\mathrm{Al}(\mathrm{IV})$ & & & \\
\hline
\end{tabular}

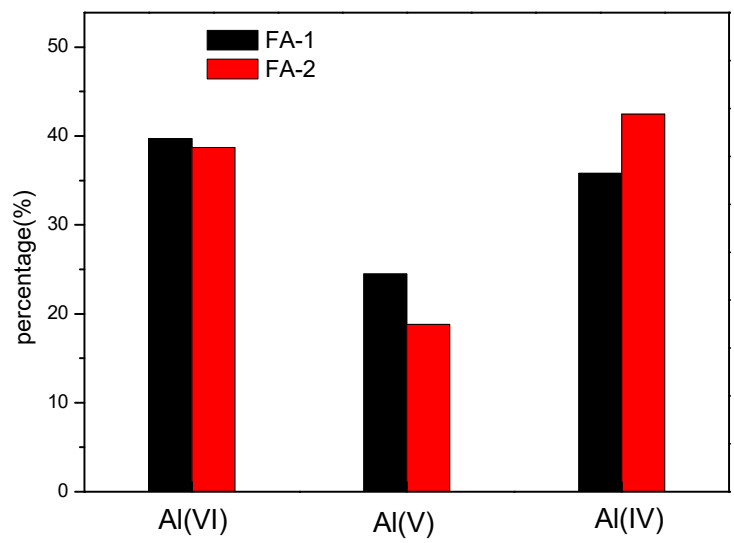

Figure 10. Comparison of the aluminium compositions for FA-1 and FA-2.

\subsection{XPS}

XPS is generally used to identify chemical bond changes for by-product fly ash in the synthesis of geopolymers. It is a highly sensitive technique, which is well-suited for examining the composition 
and chemical state of a surface [33]. Different from bulk-oriented solid-state NMR, XPS is a surface-oriented technique.

The Si 2p XPS spectra for FA-1 and FA-2 are shown in Figure 11. The fitting data are extracted from the spectra via peak fitting using XPS PEAK and are listed in Table 6. The increasing isomorphic substitution of $\mathrm{Al}^{3+}$ for $\mathrm{Si}^{4+}$ leads to a decrease in the binding energy due to the delocalization of the electrons over the silicate anion, as well as an increase in the negative charge and an increased shielding of the silicon nuclei [74]. The peak position of Si 2p at around $103 \mathrm{eV}$ indicates the presence of $\mathrm{SiO}_{2}$. The main forms of $\mathrm{Si}$ in fly ash are non-bridging $\mathrm{Si}(\mathrm{Si}-\mathrm{O})$ and bridging $\mathrm{Si}\left(\mathrm{Si}-\mathrm{O}_{2}\right)$, with binding energies of $(102.4 \pm 0.3) \mathrm{eV}$ and $(103 \pm 0.4) \mathrm{eV}$ [75]. As shown in Table 6, the content of Si-O 2 for FA-1 is $37.48 \%$ higher than $\mathrm{Si}-\mathrm{O}(28.57 \%)$, while the content of $\mathrm{Si}-\mathrm{O}_{2}$ is $30.21 \%$ lower than $\mathrm{Si}-\mathrm{O}(40.15 \%)$ for FA-2 because more substitution of $\mathrm{Al}^{3+}$ for $\mathrm{Si}^{4+}$ leads to a decrease in the number of Si-O-Si linkages and the formation of $\mathrm{Si}-\mathrm{O}-\mathrm{Al}$, which is consistent with the FTIR and ${ }^{29} \mathrm{MAS}-\mathrm{NMR}$ results. In addition to $\mathrm{Si}-\mathrm{O}$ and $\mathrm{Si}-\mathrm{O}_{2}$, there remains a peak at a high binding energy for FA-1 and FA-2. According to the standard binding energy spectrum, it was found that this peak can be assigned to $\mathrm{SiO}_{2}$ gel, which was also reported by Kanuchova [8,33].
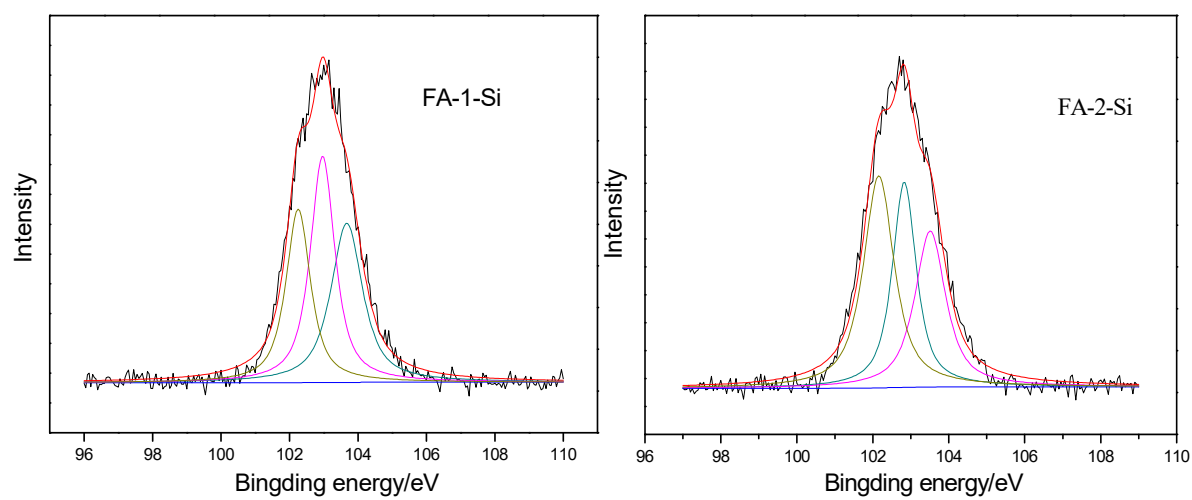

Figure 11. Si 2p X-ray photoelectron spectra (XPS) for FA-1 and FA-2.

Table 6. Fitting results of the Si $2 p$ XPS spectra.

\begin{tabular}{cccc}
\hline \multicolumn{2}{c}{ FA-1 } & \multicolumn{2}{c}{ FA-2 } \\
\hline Binding Energy/eV & Proportion/\% & Binding Energy/eV & Proportion/\% \\
\hline 102.256 & 28.57 & 102.158 & 40.15 \\
102.968 & 37.48 & 102.829 & 30.21 \\
103.674 & 33.94 & 103.511 & 29.63 \\
\hline
\end{tabular}

The Al 2p spectra clearly show that, as the Si content increases, the Al $2 p$ binding energy also increases. This is because the ionic Al-O bonds increase as the tetrahedral Si content increases. As shown in Figure 12, the binding energy of three peaks for FA-1 are higher than for FA-2, which is due to the higher $\mathrm{SiO}_{2}$ content for FA-1 compared to FA-2 [76], as shown by the chemical analysis. XPS is also capable of differentiating between tetrahedral $\mathrm{Al}$ and octahedral $\mathrm{Al}$. In general, the binding energy of octahedral $\mathrm{Al}$ is higher than tetrahedral $\mathrm{Al}$, at 74.1-75.0 eV and 73.4-74.55 eV, respectively [76]. Octahedral $\mathrm{Al}$ is the dominant form for FA- 1 with a content of $40.25 \%$ (Table 7 ), while the main form is tetrahedral Al for FA-2 with a proportion of 37.36\%. In addition, both FA-1 and FA-2 have a peak with a binding energy exceeding $75 \mathrm{eV}$, which may be assigned to the native oxide of $\mathrm{Al}$ according to the standard energy spectrum, including pentahedral $\mathrm{Al}$ or octahedral $\mathrm{Al}$ in montmorillonite [76] or other oxides. The exact nature of this phase needs to be further investigated. 

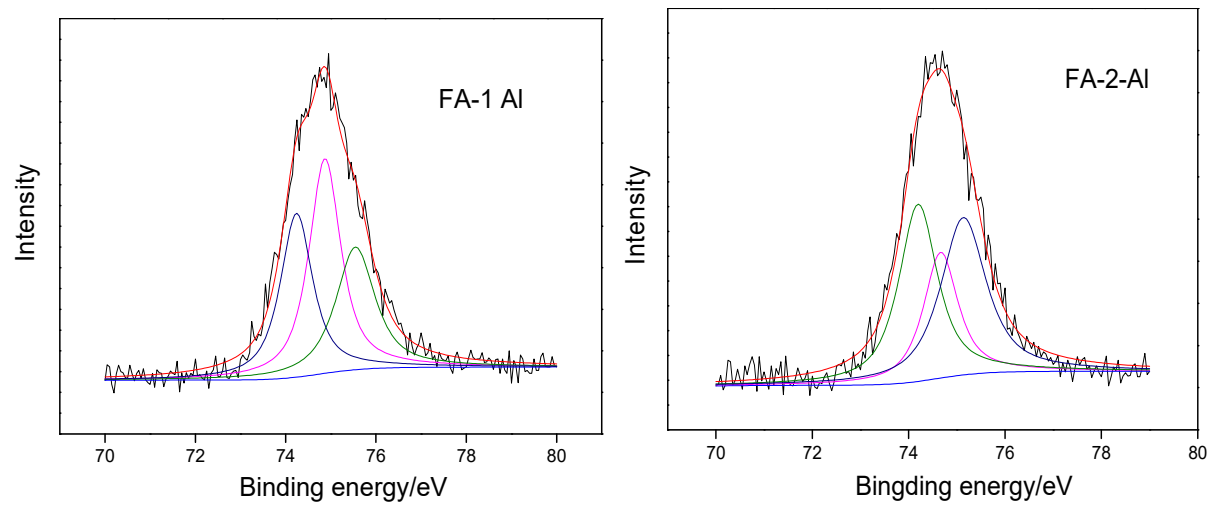

Figure 12. Al 2p XPS spectra for FA-1 and FA-2.

Table 7. Fitting results of the Al 2p XPS spectra.

\begin{tabular}{cccc}
\hline \multicolumn{2}{c}{$\begin{array}{c}\text { FA-1 } \\
\text { Proportion }\end{array}$} & \multicolumn{2}{c}{$\begin{array}{c}\text { FA-2 } \\
\text { Proportion }\end{array}$} \\
\hline Binding Energy/eV & Proportion/\% & Binding Energy/eV & Proportion/\% \\
\hline 74.241 & 31.36 & 74.197 & 37.36 \\
74.87 & 40.25 & 74.665 & 23.71 \\
75.545 & 28.39 & 75.137 & 38.93 \\
\hline
\end{tabular}

\section{Conclusions}

Compared to FA-1, there is a much greater amount of isomorphic substitution of $\mathrm{Al}^{3+}$ for $\mathrm{Si}^{4+}$ in FA-2, as verified by the FT-IR, MAS-NMR, and XPS results. Three explanations for this are that the band of asymmetric stretching vibrations $\mathrm{Si}-\mathrm{O}(\mathrm{Si})\left(1100 \mathrm{~cm}^{-1}\right)$ moves to $1090 \mathrm{~cm}^{-1}$ for FA-2, which is much lower than that for FA- $1\left(1097 \mathrm{~cm}^{-1}\right)$, that the relative contents of $\mathrm{Q}^{4}(3 \mathrm{Al})$ and $\mathrm{Q}^{4}(4 \mathrm{Al})$ of $\mathrm{FA}-2$ are higher than in FA-1, and that there is a lower content of $\mathrm{Si}-\mathrm{O}_{2}$ for FA-2.

There are three forms of $\mathrm{Si}$, bridging $\mathrm{Si}\left(\mathrm{Si}-\mathrm{O}_{2}\right)$, non-bridging $\mathrm{Si}(\mathrm{Si}-\mathrm{O})$, and $\mathrm{SiO}_{2}$ gel. FA-1 has a higher content of $\mathrm{Si}-\mathrm{O}_{2}$, while the proportion of $\mathrm{Si}-\mathrm{O}$ is much higher in FA-2. A combination of tetrahedral, pentahedral, and octahedral Al exists in both FA-1 and FA-2. Octahedral Al is the dominant form for FA-1, while the main phase is tetrahedral Al for FA-2. The slightly different contents of coordinated aluminum obtained by ${ }^{27} \mathrm{Al}$ MAS-NMR and XPS were caused by the use of different analytical methods and the inhomogeneous properties of the fly ash samples. One is a bulk-oriented method and the other one is a surface-oriented technique. The two types of fly ash were characterized by XRD, FTIR, MAS-NMR, and XPS. The detailed characterization of both types of fly ash is important for their current use as geopolymers and their potential future use for the extraction of elements of economic interest such as lithium.

Author Contributions: Writing—original draft preparation, Y.L.; supervision, B.S. and F.Z.; formal analysis, P.J.; writing-review and English editing, I.G.

Funding: This research was funded by National Key R\&D Program of China (2017YFB0603101), Shanxi Province Coal Based Low Carbon Technology Major Projects (MC2016-05), Youth Project, National Natural Science Foundation of China (No. 41602178 and No. 41802191) and NSFC-Shanxi Coal Based Low Carbon Joint Fund (U1810202).

Conflicts of Interest: The authors declare no conflict of interest.

\section{References}

1. Zhao, S.L.; Duan, Y.F.; Liu, M.; Wang, C.P.; Zhou, Q.; Lu, J.H. Effects on enrichment characteristics of trace elements in fly ash by adding halide salts into the coal during CFB combustion. J. Energy Inst. 2018, 91, 214-221. [CrossRef]

2. Dai, S.; Finkelman, R.B. Coal as a promising source of critical elements: Progress and future prospects. Int. J. Coal Geol. 2018, 186, 155-164. [CrossRef] 
3. Yuan, C.G. Leaching characteristics of metals in fly ash from coal-fired power plant by sequential extraction procedure. Microchim. Acta. 2009, 165, 91-96. [CrossRef]

4. Koukouzas, N.; Ketikidis, C.; Itskos, G. Heavy metal characterization of CFB-derived coal fly ash. Fuel Process. Technol. 2011, 92, 441-446. [CrossRef]

5. Duan, S.Y.; Liao, H.Q.; Song, H.P.; Cheng, F.Q. Physical and Chemical properties studies of fly ash from two typical coal-Fired boiler. In Proceedings of the 1st Conference on Solid Waste Utilization and Eco-materials, Beijing, China, 1-2 August 2015; p. 226. (In Chinese).

6. Hower, J.C.; Groppo, J.G.; Graham, U.M.; Ward, C.R.; Kostova, I.J.; Maroto-Valer, M.M.; Dai, S. Coal-derived unburned carbons in fly ash: A review. Int. J. Coal Geol. 2017, 179, 11-27. [CrossRef]

7. Mukherjee, A.B.; Zevenhoven, R.; Bhattacharya, P.; Sajwan, K.S.; Kikuchi, R. Mercury flow via coal and coal utilization by-products: A global perspective. Resour., Conserv. Recycl. 2008, 52, 571-591. [CrossRef]

8. Kanuchova, M.; Drabova, M.; Sisol, M.; Mosej, J.; L'ubica, K.; Skvarla, J. Influence of Mechanical Activation of Fly Ash on the Properties of Geopolymers Investigated by XPS Method. Environ. Prog. Sustain. Energy 2016, 35, 1338-1343. [CrossRef]

9. Koukouzas, N.; Ketikidis, C.; Itskos, G.; Spiliotis, X.; Karayannis, V.; Papapolymerou, G. Synthesis of CFB-Coal Fly Ash Clay Bricks and Their Characterisation. Waste Biomass Valorization. 2011, 2, 87-94. [CrossRef]

10. Rong, J.X.; Yan, K.H.; Bin, T.; Si, H.S. Experimental Study of CFB Modification Fly Ash in Concrete. Adv. Mater. Res. 2014, 1051, 743-747. [CrossRef]

11. Ahmaruzzaman, M.A. Review on the Utilization of Fly Ash. Prog. Energy Combust. Sci. 2010, 36, 327-363. [CrossRef]

12. Dai, S.; Zhao, L.; Peng, S.; Chou, C.-L.; Wang, X.; Zhang, Y.; Li, D.; Sun, Y. Abundances and distribution of minerals and elements in high-alumina coal fly ash from the Jungar Power Plant, Inner Mongolia, China. Int. J. Coal Geol. 2010, 81, 320-332. [CrossRef]

13. Seredin, V.V.; Dai, S.; Sun, Y.; Chekryzhov, I.Y. Coal deposits as promising sources of rare metals for alternative power and energy-efficient technologies. Appl. Geochem. 2013, 31, 1-11. [CrossRef]

14. Hower, J.C.; Qian, D.L.; Briot, N.J.; Henke, K.R.; Hood, M.M.; Taggart, R.K.; Hsu-Kim, H. Rare earth element associations in the Kentucky State University stoker ash. Int. J. Coal Geol. 2018, 189, 75-82. [CrossRef]

15. King, J.F.; Taggart, R.K.; Smith, R.C.; Hower, J.C.; Hsu-Kim, H. Aqueous acid and alkaline extraction of rare earth elements from coal combustion ash. Int. J. Coal Geol. 2018, 195, 75-83. [CrossRef]

16. Kolker, A.; Scott, C.; Hower, J.C.; Vazquez, J.A.; Lopano, C.L.; Dai, S. Distribution of rare earth elements in coal combustion fly ash, determined by SHRIMP-RG ion microprobe. Int. J. Coal Geol. 2017, 184, 1-10. [CrossRef]

17. Laudal, D.A.; Benson, S.A.; Addleman, R.S.; Palo, D. Leaching behavior of rare earth elements in fort union lignite coals of North America. Int. J. Coal Geol. 2018, 191, 112-124. [CrossRef]

18. Stuckman, M.Y.; Lopano, C.L.; Granite, E.J. Distribution and speciation of rare earth elements in coal combustion by-products via synchrotron microscopy and spectroscopy. Int. J. Coal Geol. 2018, 195, 125-138. [CrossRef]

19. Zhang, W.C.; Honaker, R.Q. Rare earth elements recovery using staged precipitation from a leachate generated from coarse coal refuse. Int. J. Coal Geol. 2018, 195, 189-199. [CrossRef]

20. Wang, Z.; Dai, S.; Zou, J.H.; French, D.; Graham, I.T. Rare earth elements and yttrium in coal ash from the Luzhou power plant in Sichuan, Southwest China: Concentration, characterization and optimized extraction. Int. J. Coal Geol. 2019, 203, 1-14. [CrossRef]

21. Dai, S.; Seredin, V.V.; Colin, C.R.; Jiang, J.H.; Hower, J.C.; Song, X.; Jiang, Y.; Wang, X.; Gornostaeva, T.; Li, X.; et al. Composition and modes of occurrence of minerals and elements in coal combustion products derived from high-Ge coals. Int. J. Coal Geol. 2014, 121, 79-97. [CrossRef]

22. Sun, Y.Z.; Zhao, C.L.; Li, Y.H.; Wang, J.X.; Liu, S.M. Li Distribution and Mode of Occurrences in Li-Bearing Coal Seam \# 6 from the Guanbanwusu Mine, Inner Mongolia, Northern China. Energy Explor. Exploit. 2012, 30, 109-130. [CrossRef]

23. Hu, P.P.; Hou, X.J.; Zhang, J.B.; Li, S.P.; Wu, H.; Damø, A.J.; Li, H.Q.; Wu, Q.S.; Xi, X.G. Distribution and occurrence of lithium in high-alumina-coal fly ash. Int. J. Coal Geol. 2018, 189, 27-34. [CrossRef]

24. Dai, S.; Graham, I.T.; Ward, C.R. A review of anomalous rare earth elements and yttrium in coal. Int. J. Coal Geol. 2016, 159, 82-95. [CrossRef] 
25. Dai, S.; Seredin, V.V.; Ward, C.R.; Hower, J.C.; Xing, Y.; Zhang, W.; Song, W.; Wang, P. Enrichment of $\mathrm{U}-\mathrm{Se}-\mathrm{Mo}-\mathrm{Re}-\mathrm{V}$ in coals preserved within marine carbonate successions: Geochemical and mineralogical data from the Late Permian Guiding Coalfield, Guizhou, China. Miner. Deposita. 2015, 50, 159-186. [CrossRef]

26. Dai, S.; Yan, X.; Ward, C.R.; Hower, J.C.; Lei, Z.; Wang, X.; Zhao, L.; Ren, D.; Finkelman, R.B. Valuable elements in Chinese coals: A review. Int. Geol. Rev. 2016, 60, 590-620. [CrossRef]

27. Hower, J.C.; Dai, S. Petrology and chemistry of sized Pennsylvania anthracite, with emphasis on the distribution of rare earth elements. Fuel 2016, 185, 305-315. [CrossRef]

28. Hower, J.C.; Eble, C.F.; Dai, S.; Belkin, H.E. Distribution of rare earth elements in eastern Kentucky coals: Indicators of multiple modes of enrichment? Int. J. Coal Geol. 2016, 160-161, 73-81. [CrossRef]

29. Seredin, V.V.; Dai, S. The occurrence of gold in fly ash derived from high-Ge coal. Miner. Deposita. 2014, 49, 1-6. [CrossRef]

30. Zhang, J.B.; Li, S.P.; Li, H.Q.; He, M.M. Acid activation for pre-desilicated high-alumina fly ash. Fuel Process. Technol. 2016, 151, 64-71. [CrossRef]

31. Mozgawa, W.; Król, M.; Dyczek, J.; Deja, J. Investigation of the coal fly ashes using IR spectroscopy. Spectrochim. Acta 2014, 132, 889-894. [CrossRef]

32. Gao, X.; Yu, Q.L.; Brouwers, H.J.H. Apply ${ }^{29} \mathrm{Si},{ }^{27} \mathrm{Al}$ MAS NMR and selective dissolution in identifying the reaction degree of alkali activated slag-fly ash composites. Ceram. Int. 2017, 43, 12408-12419. [CrossRef]

33. Kanuchova, M.; Ĺubica, K.; Drabova, M.; Sisol, M.; Estokova, A.; Kaňuch, J.; Skvarla, J. Monitoring and characterization of creation of geopolymers prepared from fly ash and metakaolin by X-ray photoelectron spectroscopy method. Environ. Prog. Sustain. Energy 2014, 34, 841-849. [CrossRef]

34. Wyatt, P.J. Some chemical, physical, and optical properties of fly ash particles. Appl. Opt. 1980, 19, 975-983. [CrossRef]

35. El-Mogazi, D.; Lisk, D.J.; Weinstein, L.H. A review of physical, chemical, and biological properties of fly ash and effects on agricultural ecosystems. Sci. Total Environ. 1988, 74, 1-37. [CrossRef]

36. Qi, L.; Jing, H.; Gregoire, D.C. Determination of trace elements in granites by inductively coupled plasma mass spectrometry. Talanta 2000, 51, 507-513. [CrossRef]

37. Methods for Chemical Analysis of Silicate Rocks-P 3: Determination of Silicon Dioxide Content. Patent GB/T 14506.3-2010, 10 November 2010. (In Chinese).

38. Li, L.Z. Rock and Mineral Analysis; Geological Publishing House: Beijing, China, 1991; Volume 1. (In Chinese)

39. Wang, Z.Y. Quantitative determination of aluminum and silicon elements in corundum, kaolin clay and mullite. Chin. J. Inorg. Anal. Chem. 2011, 1, 35-38. (In Chinese) [CrossRef]

40. Chen, Y.J.; Li, Q.; Jiang, D.Y. Study on the Glassy Phase Composition of $95 \mathrm{Al}_{2} \mathrm{O}_{3}$ Ceramics. Key Eng. Mater. 2011, 492, 463-466. [CrossRef]

41. Ciesielczyk, F.; Bartczak, P.; Jesionowski, T. A comprehensive study of Cd(II) ions removal utilizing high-surface-area binary Mg-Si hybrid oxide adsorbent. Int. J. Environ. Sci. Technol. 2015, 12, 3613-3626. [CrossRef]

42. Chen, Y.Y.; Mastalerz, M.; Schimmelmann, A. Characterization of chemical functional groups in macerals across different coal ranks via micro-FTIR spectroscopy. Int. J. Coal Geol. 2012, 104, 22-33. [CrossRef]

43. Strydom, C.A.; Bunt, J.R.; Schobert, H.H.; Raghoo, M. Changes to the organic functional groups of an inertinite rich medium rank bituminous coal during acid treatment processes. Fuel Process. Technol. 2011, 92, 764-770. [CrossRef]

44. Hahn, A.; Vogel, H.; Andó, S.; Garzanti, E.; Kuhn, G.; Lantzsch, H.; Schüürman, J.; Vogt, C.; Zabel, M. Using Fourier Transform Infrared Spectroscopy to determine mineral phases in sediments. Sediment. Geol. 2018, 375, 27-35. [CrossRef]

45. Palomo, Á.; Alonso, S.; Fernandez-Jiménez, A.; Sobrados, I.; Sanz, J. Alkaline Activation of Fly Ashes: NMR Study of the Reaction Products. J. Am. Ceram. Soc. 2010, 87, 1141-1145. [CrossRef]

46. Dai, S.; Ren, D.; Chou, C.-L.; Finkelman, R.B.; Seredin, V.V.; Zhou, Y. Geochemistry of trace elements in Chinese coals: A review of abundances, genetic types, impacts on human health, and industrial utilization. Int. J. Coal Geol. 2012, 94, 3-21. [CrossRef]

47. Ketris, M.P.; Yudovich, Y.E. Estimations of Clarkes for Carbonaceous biolithes: World averages for trace element contents in black shales and coals. Int. J. Coal Geol. 2009, 78, 135-148. [CrossRef]

48. Liu, H.D. Composition of the Coal Combustion and Utilization of the Fly Ash Generated from Two Major Coal-fired Power Plants in Chongqing city, Southwest China. Ph.D. Thesis, China University of Mining \& Technology, Beijing, China, 2015. (In Chinese). 
49. Huang, Y.; Qian, J.S.; Wang, Z.; Zhang, Z.W. Comparative Study of CFB Ashes and PC Ashes. Fly Ash Compr. Util. 2009, 3, 7-9. (In Chinese) [CrossRef]

50. Wang, E. Mineralogy Properties Comparison of PC Fly Ash and CFB Fly Ash. Clean Coal Technol. 2016, 22, $26-29$. (In Chinese) [CrossRef]

51. Spears, D.A. Role of clay minerals in UK coal combustion. Appl. Clay Sci. 2000, 16, 87-95. [CrossRef]

52. Henry, J.; Towler, M.R.; Stanton, K.T.; Querol, X.; Moreno, N. Characterization of the Glass Fraction of a Selection of European Coal Fly Ashes. J. Chem. Technol. Biotechnol. 2010, 79, 540-546. [CrossRef]

53. Painter, P.C.; Coleman, M.M.; Jenkins, R.G.; Whang, P.W.; Walker, P.L., Jr. Fourier Transform Infrared study of mineral matter in coal. A novel method for quantitative mineralogical analysis. Fuel 1978, 57, 337-344. [CrossRef]

54. Mukherjee, S.; Srivastava, S.K. Minerals Transformations in Northeastern Region Coals of India on Heat Treatment. Energy Fuels 2006, 20, 1089-1096. [CrossRef]

55. De Benedetto, G.E.; Laviano, R.; Sabbatini, L.; Zambonin, P.G. Infrared spectroscopy in the mineralogical characterization of ancient pottery. J. Cult. Herit. 2002, 3, 177-186. [CrossRef]

56. Wu, L.M.; Tong, D.S.; Zhao, L.Z.; Yu, W.H.; Zhou, C.H.; Wang, H. Fourier transform infrared spectroscopy analysis for hydrothermal transformation of microcrystalline cellulose on montmorillonite. Appl. Clay Sci. 2014, 95, 74-82. [CrossRef]

57. Angaji, M.T.; Zinali, A.Z.; Qazvini, N.T. Study of Physical, Chemical and Morphological Alterations of Smectite Clay upon Activation and Functionalization via the Acid Treatment. World J. Nano Sci. Eng. 2013, 3, 161-168. [CrossRef]

58. Flanigen, E.M.; Khatamt, H.; Szymanski, H.A. Infrared Structural Studies of Zeolite Frameworks. Adv. Chem. 1971, 101, 201-228. [CrossRef]

59. Fernández-Jiménez, A.; Palomo, A. Mid-infrared spectroscopic studies of alkali-activated fly ash structure. Microporous Mesoporous Mater. 2005, 86, 207-214. [CrossRef]

60. Bernal, S.A.; Provis, J.L.; Walkley, B.; Nicolas, R.S.; Gehman, J.D.; Brice, D.G.; Kilcullen, A.R.; Duxson, P.; Deventer, J.S.J.V. Gel nanostructure in alkali-activated binders based on slag and fly ash, and effects of accelerated carbonation. Cem. Concr. Res. 2013, 53, 127-144. [CrossRef]

61. Lee, N.K.; Lee, H.K. Reactivity and reaction products of alkali-activated, fly ash/slag paste. Constr. Build. Mater. 2015, 81, 303-312. [CrossRef]

62. Saoût, G.L.; Haha, M.B.; Winnefeld, F.; Lothenbach, B. Hydration Degree of Alkali-Activated Slags: A ${ }^{29} \mathrm{Si}$ NMR Study. J. Am. Ceram. Soc. 2011, 94, 4541-4547. [CrossRef]

63. Walkley, B.; Nicolas, R.S.; Sani, M.A.; Gehman, J.D.; Deventer, J.S.J.V.; Provis, J.L. Synthesis of stoichiometrically controlled reactive aluminosilicate and calcium-aluminosilicate powders. Powder Technol. 2016, 297, 17-33. [CrossRef]

64. Brough, A.R.; Atkinson, A. Sodium silicate-based, alkali-activated slag mortars: Part I. Strength, hydration and microstructure. Cem. Concr. Res. 2002, 32, 865-879. [CrossRef]

65. Park, S.M.; Jang, J.G.; Lee, N.K.; Lee, H.K. Physicochemical properties of binder gel in alkali-activated fly ash/slag exposed to high temperatures. Cem. Concr. Res. 2016, 89, 72-79. [CrossRef]

66. Rejmak, P.; Dolado, J.S.; Stott, M.J.; Ayuela, A. ${ }^{29}$ Si NMR in Cement: A Theoretical Study on Calcium Silicate Hydrates. J. Phys. Chem. C 2012, 116, 9755-9761. [CrossRef]

67. Criado, M.; Fernández-Jiménez, A.; Palomo, A.; Sobrados, I.; Sanz, J. Effect of the $\mathrm{SiO}_{2} / \mathrm{Na}_{2} \mathrm{O}$ ratio on the alkali activation of fly ash. Part II: ${ }^{29}$ Si MAS-NMR Survey. Microporous Mesoporous Mater. 2008, 109, 525-534. [CrossRef]

68. Fernández-Jiménez, A.; Palomo, A. Characterisation of fly ashes. Potential reactivity as alkaline cements. Fuel 2003, 82, 2259-2265. [CrossRef]

69. Fernández-Jiménez, A.; Torre, A.G.D.L.; Palomo, A.; López-Olmo, G.; Alonso, M.M.; Aranda, M.A.G. Quantitative determination of phases in the alkaline activation of fly ash. Part II: Degree of reaction. Fuel 1960, 85, 1960-1969. [CrossRef]

70. Kovalchuk, G.; Fernández-Jiménez, A.; Palomo, A. Alkali-activated fly ash: Effect of thermal curing conditions on mechanical and microstructural development-Part II. Fuel 2007, 86, 315-322. [CrossRef]

71. Peng, Z.H.; Vance, K.; Dakhane, A.; Marzke, R.; Neithalath, N. Microstructural and ${ }^{29}$ Si MAS NMR spectroscopic evaluations of alkali cationic effects on fly ash activation. Cem. Concr. Compos. 2015, 57, $34-43$. [CrossRef] 
72. Merwin, L.H.; Sebald, A.; Rager, H.; Schneider, H. ${ }^{29} \mathrm{Si}$ and ${ }^{27} \mathrm{Al}$ MAS NMR spectroscopy of mullite. Phys. Chem. Miner. 1991, 18, 47-52. [CrossRef]

73. Wang, Z.R. Mineralogy; Shanghai Science and Technology Press: Shanghai, China, 1965. (In Chinese)

74. Black, L.; Stumm, A.; Garbev, K.; Stemmermann, P.; Hallam, K.C.; Allen, G. X-ray photoelectron spectroscopy of aluminium-substituted tobermorite. Cem. Concr. Res. 2005, 35, 51-55. [CrossRef]

75. Wen, H.T.; Kong, L.X.; Bai, J.; Bai, Z.Q.; Lv, D.M.; Li, W. Research on the transformation of mineral structure of high ash fusion temperature coal ash by XPS Journal of Fuel. Chem. Techenol. 2015, 43, 257-265. (In Chinese) [CrossRef]

76. Barr, T.L.; Seal, S.; Wozniak, K.; Klinowski, J. ESCA studies of the coordination state of aluminium in oxide environments. J. Chem. Soc. Faraday Trans. 1997, 93, 181-186. [CrossRef]

(C) 2019 by the authors. Licensee MDPI, Basel, Switzerland. This article is an open access article distributed under the terms and conditions of the Creative Commons Attribution (CC BY) license (http://creativecommons.org/licenses/by/4.0/). 